\title{
NMR structure of mussel mytilin, and antiviral-antibacterial activities of derived synthetic peptides
}

\author{
Philippe Roch ${ }^{a,{ }^{*}}$, Yinshan Yang $^{b}$, Mylène Toubiana ${ }^{a}$ and André Aumelas ${ }^{b}$
}

\author{
a CNRS UMR5119-IFREMER-Université Montpellier 2, Ecosystèmes Lagunaires, cc093, place E. Bataillon, F- \\ 34095 Montpellier, France \\ ${ }^{\mathrm{b}}$ CNRS UMR5048-INSERM U554-Universités Montpellier 1 et 2, Centre de Biochimie Structurale, 29, rue de \\ Navacelles, F-34090 Montpellier, France
}

*: Corresponding author : P. Roch, email address : proch@univ-montp2.fr

\begin{abstract}
:
Mytilin is a 34-residue antibacterial peptide from the mussel Mytilus galloprovincialis, which in addition possesses in vitro antiviral activity. The three-dimensional solution structure of the synthetic mytilin was established by using $1 \mathrm{H}$ NMR and consists of the common cysteine-stabilized $\alpha \beta$ motif close to the one observed in the mussel defensin MGD-1. Mytilin is characterized by 8 cysteines engaged in four disulfide bonds $(2-27,6-29,10-31$, and $15-34)$ only involving the $\beta$-strand II. Hydrophilic and hydrophobic areas of mytilin account for $63 \%$ and $37 \%$, respectively, a ratio very close to that of MGD$1(64 \%$ and $36 \%)$. One linear and three cyclic fragments were designed from the interstrand loop sequence known to retain the biological activities in MGD-1. Only the fragment of 10 amino acids (C10C) constrained by two disulfide bonds in a stable $\beta$-hairpin structure was able to inhibit the mortality of Palaemon serratus shrimp injected with white spot syndrome virus (WSSV). Fifty percent inhibition was obtained by in vitro pre-incubation of WSSV with $45 \mu \mathrm{M}$ of C10C compared with $7 \mu \mathrm{M}$ for mytilin. Interaction between the fragment and the virus occurred very rapidly as $40 \%$ survival was recorded after only $1 \mathrm{~min}$ of pre-incubation. In addition, C10C was capable of inhibiting in vitro growth of Vibrio splendidus LGP32 (MIC $125 \mu \mathrm{M}$ ), Vibrio anguillarum (MIC $2 \mathrm{mM}$ ), Micrococcus lysodeikticus and Escherichia coli (MIC $1 \mathrm{mM}$ ). Destroying the cysteine-stabilized $\alpha \beta$ structure or shortening the $\mathrm{C} 10 \mathrm{C}$ fragment to the $\mathrm{C6C}$ fragment with only one disulfide bond resulted in loss of both antiviral and antibacterial activities. Increasing the positive net charge did not enforce the antibacterial activity and completely suppressed the antiviral one. The C10C-designed peptide from mytilin appeared comparable in composition and structure with protegrin, tachyplesin and polyphemusin.
\end{abstract}

Keywords: Antimicrobial peptide; Mytilin; NMR; $\beta$-Hairpin structure; Viral protection; WSSV; Antibacterial activity; Mussel; Molluscs; Shrimp

Abbreviations: AMP, antimicrobial peptide; DQF-COSY, double-quantum-filtered correlated spectroscopy; MBC, minimal bactericidal concentration; MIC, minimal inhibitory concentration; NMR, nuclear magnetic resonance; NOE, nuclear Overhauser effect; NOESY, nuclear Overhauser effect spectroscopy; rmsd, root-mean-square deviation; TN, 20 mM Tris- $\mathrm{HCl}$, pH 7.4, 400 mM NaCl; WSSV, white spot syndrome virus; z-TOCSY, z-filtered total correlated spectroscopy 


\section{Introduction}

On the opposite to antibacterial capabilities, few papers addressed antiviral activities in invertebrates and no interferon-like molecule has been reported, either at the proteomic or genomic level. Meanwhile, numerous antimicrobial peptides (AMP) were described as capable of inactivating various viruses [1-3]. Despite an enormous biotechnology interest, this point is still controversial, as constitutive expression of one AMP did not provide resistance to viral infection in Drosophila, for instance [4]. In addition, commonly admitted AMP mechanisms of membrane disruption did not apply to virus capside [5].

First researches of AMP in bivalve Molluscs were in the 90's through reverse genomic, i.e. from biochemical purification of active peptides, to cDNA and gene sequencing. In Mytilus, the three families of defensin, mytilin and myticin, were characterized by 34-40 amino acids in the active peptide including 8 cysteines engaged in 4 intra molecular disulfide bonds (see [6] for review). The forth AMP, mytimycin, was only reported by Charlet et al [7] as a $6.5 \mathrm{kDa}$ antifungal peptide possessing 12 cysteines. Since that time, EST analyses have been extensively applied to identify proteomes involved in different metabolic responses. Several attempts failed to reveal any Mytilus-like AMP in embryos and hemocytes from unchallenged oyster, Crassostrea virginica [8], in hemocytes from C. gigas challenged with Vibrio bacterial cocktail [9], in hemocytes and gills from both C. gigas and C. virginica experimentally challenged with the protozoan, Perkinsus marinus [10], and in free-swimming sperm from both $C$. gigas and $C$. virginica using the bacterial artificial chromosome technology [11]. Finally, Mytilus-like defensins were identified in oyster by biochemical purification of an acidified gill extract from unchallenged C. virginica (38 amino acids, 6 cysteines) [12]. Subsequently, others defensin-like AMP have been discovered by EST analysis of mantle edge from C. gigas (43 amino acids, 8 cysteines)[13], of whole body extract except digestive tracts and intestines from Bay scallop, Argopecten irradians [14], and from hemocytes of C. gigas challenged with a cocktail of heat killed bacteria (43 amino acids, 8 cysteines, 2 isoforms) [15].

Until now, solution structures of bivalve AMPs have been established only for the mussel, $M$. galloprovincialis [16] and for the oyster, C. gigas [13] defensins. Although the two peptides display only $50 \%$ of sequence identity, their tri-dimensional structures are comparable with an $\alpha$-helix followed by a two-stranded $\beta$-sheet tightly linked together by a similar pattern of four disulfide bonds. In addition, bivalve defensin structures are closely related to the one of arthropod, Phormia terranovae, larvae defensin although possessing only $38.5 \%$ sequence identity and only three disulfide bonds [17].

Previous report on antibacterial/anti-fungal activity of mussel defensin truncated sequences revealed the key role of the loop connecting the two beta-strands [18]. Such truncated sequences also displayed antiviral activity [2]. According to the specific activities of the various sequences, including amino acid replacements and increased positive net charge, anti viral activity and anti bacterial-anti protozoan activities, appeared mediated by different mechanisms [2,[18]. On the opposite, a fragment of mytilin designed according to the defensin structure was reported as not inhibitory [3].

To gain further insight into the structural requirement for antiviral activity of AMP, we focussed on mytilin, (i) to establish the solution structure of the synthetic peptide, (ii) to synthesize designed fragments corresponding to the loop linking the two $\beta$-strands, and (iii) to check for their ability to inhibit shrimp infestation by WSSV compared to in vitro antibacterial activity towards both Gram negative and Gram positive bacteria.

\section{Materials and Methods}

\subsection{Shrimp, virus and bacteria}

Shrimp from native species, Palaemon serratus (Palaemonidae family), and from introduced species, Litopenaeus japonicus (Panaeidae family), were purchased from local market (Montpellier-France) at the adult size of $4-6 \mathrm{~cm}$, and maintained at $22^{\circ} \mathrm{C}$ in tanks of $50 \mathrm{~L}$ with circulating seawater.

WSSV is a large double-stranded circular DNA virus of nearly $293 \mathrm{kbp}$ encompassing 184 open reading frames [19]. WSSV were purified from infected Penaeus monodon cephalothoraxes obtained from D.V. Lightner, University of Arizona-Tucson. Crude extracts of viruses were purified from $1 \mathrm{~g}$ of 
tissue homogenised in $20 \mathrm{mM}$ Tris- $\mathrm{HCl}, \mathrm{pH} 7.4,400 \mathrm{mM} \mathrm{NaCl}$ (TN). The solution was clarified by 10 min centrifugation at $1,000 \times \mathrm{xg}, 4^{\circ} \mathrm{C}$ and the supernatant was centrifuged again during $45 \mathrm{~min}$ at $20,000 \times g, 4^{\circ} \mathrm{C}$. The pellet containing WSSV was re-suspended in $5 \mathrm{ml} \mathrm{TN}$, and centrifuged during 10 min at $1,000 \mathrm{xg}, 4^{\circ} \mathrm{C}$. The supernatant was distributed in $1 \mathrm{ml}$ aliquots and used immediately. No more precise quantification of virus particles was done as no cell culture was available to evaluate the number of infective virions.

Gram negative Vibrio splendidus strain LGP32 was isolated from juvenile oysters, Crassostrea gigas, during summer 2001 mortalities [20]. Vibrio anguillarum (ATCC 19264) and Micrococcus lysodeikticus (ATCC 4698) were from Institut Pasteur-France. Escherichia coli were from TOPO TA Cloning kit (Invitrogen).

\subsection{Synthesis and structure of mytilin}

Linear mytilin was synthesized by Epytop (Nîmes-France) according to mytilin B amino acid sequence (GenBank P81613). Its C-terminus was amidated (Table 1). The oxidative folding of the linear mytilin was carried out with a $1 \mathrm{mM}$ peptide solution in a $10 \mathrm{mM}$ TRIS-HCl buffer $(\mathrm{pH} 8.5)$ at room temperature and monitored by $1 \mathrm{H}-\mathrm{NMR}$. In the initial spectrum, amide signals were gathered in a narrow chemical shift area (from 8.8 to $7.8 \mathrm{ppm}$ ) typical for random coil peptides. Progressively, new signals appeared and grew up. These new signals were spread out on a large chemical shift area (from 9.7 to $6.8 \mathrm{ppm}$ ) typical for a peptide with a well-defined structure. After $24 \mathrm{~h}$, the yield in the folded peptide has been estimated to $\approx 90 \%$ by integration of typical signals of the folded and linear mytilin. The mixture was purified to homogeneity by HPLC on a reversed-phase column (Symetry Shield TM RP18; 4.6x250; 5 $\mathrm{mm}$; Waters) with a linear acidified water-acetonitrile gradient. Finally, the fractions containing the folded mytilin were pooled, lyophilized and kept as dry powder.

\subsection{NMR spectroscopy}

Samples of synthetic mytilin for nuclear magnetic resonance (NMR) analysis were prepared in a 95:5 $(\mathrm{v} / \mathrm{v})$ mixture of $\mathrm{H}_{2} \mathrm{O}$ and $\mathrm{D}_{2} \mathrm{O}$ to yield $0.8-1.0 \mathrm{mM}$ solutions. The $\mathrm{pH}$ was adjusted to the desired value by adding $\mathrm{DCl}$ or $\mathrm{NaOD}$ and was checked at room temperature with a $3 \mathrm{~mm}$ electrode. The $\mathrm{pH}$ values given have not been corrected for the deuterium isotopic effect. Proton chemical shifts are expressed with respect to sodium 4,4-dimethyl-4-silapentane-1-sulfonate, according to the IUPAC recommendations. We carried out $1 \mathrm{H}$ NMR experiments on a Bruker Avance 600 spectrometer equipped with a triple-resonance cryoprobe, and spectra were recorded at $\mathrm{pH} 3.3$ and temperatures ranging from 17 to $32^{\circ} \mathrm{C}$. In all experiments, the carrier frequency was set at the centre of the spectrum, at the frequency of water. Spectra produced by double-quantum-filtered correlated spectroscopy (DQF-COSY) [21, 22], z-filtered total correlated spectroscopy (z-TOCSY) [23, 24], and nuclear Overhauser effect spectroscopy (NOESY) [25] were acquired in the phase-sensitive mode, using the States-TPPI method [26]. For spectra recorded in $\mathrm{H}_{2} \mathrm{O}$, the resonance of the water was suppressed by the WATERGATE method [27], except for DQF-COSY spectra, for which low-power irradiation was used. z-TOCSY spectra were obtained with a mixing time of $90 \mathrm{~ms}$, and NOESY spectra with a mixing time of $220 \mathrm{~ms}$. The NMR samples of the C10C and C6C synthetic peptides were prepared in a 95:5 (v/v) mixture of $\mathrm{H}_{2} \mathrm{O}$ and $\mathrm{D}_{2} \mathrm{O}$ to yield 1.5-2 mM solutions and TOCSY, COSY and NOESY data were recorded at $17^{\circ} \mathrm{C}$. All data were processed either with the XWINNMR or the GIFA softwares [28]. Full sequential assignment was achieved using the general strategy described by Wüthrich [29].

\subsection{Structure calculation}

The NOESY cross-peaks were measured from the NOESY spectrum recorded at $22^{\circ} \mathrm{C}$ and were divided into five classes, according to their intensities. Very strong, strong, medium, weak, and very weak NOEs were then converted into 1.8-2.4, 1.8-2.8, 1.8-3.6, 1.8-4.4, and 1.8-5.0 $\AA$ distance constraints, respectively. For equivalent protons or non-stereo specifically assigned protons, pseudoatoms were introduced. The $\phi$ angle restraints were derived from the $3 \mathrm{JHN}-\mathrm{C} \alpha \mathrm{H}$ coupling constants, and the $\chi^{1}$ angle restraints were derived from the combined analysis of the $3 \mathrm{JH} \tilde{\alpha} \mathrm{H} \beta \beta$ coupling 
constants and intra-residues NOEs, respectively. To calculate 3D structures, these distance and dihedral angle restraints were used as input in the standard distance geometry (DG)/simulated annealing (SA) refinement and energy-minimization protocol using X-PLOR 3.8 [30]. In the first stage of the calculation, an initial ensemble of 60 structures was generated from a template structure with randomized $\phi, \varphi$ dihedral angles and extended side chains, using a DG protocol followed by restrained $\mathrm{SA}$ and refinement [31]. No hydrogen bond restraint was used. Since the arrangement of the disulfide bonds had to be determined, structures were generated without using any disulfide bond constraints. Analyzing the obtained structures and comparing them with the NMR data allowed identifying more additional NOE restraints, which were introduced into the subsequent calculation. After a number of these processes, 474 NOE-derived distance restraints (110 medium range and 108 long range) and 46 dihedral angles ( $26 \phi, 17 \chi 1$ and $3 \chi 3$ ) were used as final input data. Analysis of the average $S \gamma-S \gamma$ distances in the lowest energy structures allowed us to unambiguously determine the arrangement of the four disulfide bonds. Finally, a calculation of 60 conformers including the disulfide bonds was carried out, and the resulting 20 best structures with a minimum of restrained violations were submitted to 5,000 cycles of restrained Powell energy minimization. The solution structure of the C10C peptide was obtained with the same calculation protocol. 62 NMR-derived distance constraints were identified from the NOESY spectrum recorded at $17^{\circ} \mathrm{C}$ with a mixing time of $200 \mathrm{~ms}$. These constraints were used as input data to calculate 60 conformers and the resulting 10 best structures were selected.

\subsection{Structure Analysis}

The visual display and the calculation of root-mean-square deviations (rmsd) were performed with INSIGHT 97 (Molecular Simulation Inc.). Hydrogen bonds were considered as present if the distance between heavy atoms was less than $3.5 \AA$ and the donor-hydrogen-acceptor angle was greater than $120^{\circ}$. Ramachandran analysis were performed with PROCHECK [32], and the limits of the secondary structure elements and the van der Waals surfaces were determined with the STRIDE program [33]. The chemical shifts and coordinates of the energy-minimized conformers of mytilin are deposited in the BMRB (entry code 15140) and in the PDB (entry code 2EEM), respectively.

\subsection{Design and synthesis of fragments}

The amino acid sequence corresponding to the $\beta$-hairpin structure of mytilin (Fig. 2) was used to design one linear (S10S) and three cyclic peptides (C6C, C10C, and C10C+) (Table 1). These peptides were synthesized by Genepep (Montpellier-France). Their $\mathrm{N}$ - and $\mathrm{C}$-terminal residues were acetylated and amidated, respectively, to eliminate the terminal charges.

\subsection{In vitro contact WSSV-peptides and in vivo challenge}

Aliquots of WSSV preparations were incubated at $20^{\circ} \mathrm{C}$ during 30 min under agitation in $1 \mathrm{ml}$ solution of mytilin or fragments at corresponding concentrations. The viruses were then concentrated by 45 min centrifugation at $20,000 \mathrm{xg}, 4^{\circ} \mathrm{C}$ to eliminate excess of peptides. Pellets were dissolved in $5 \mathrm{ml}$ TN and immediately used for injections. Injections of $50 \mu \mathrm{l}$ were done in the posterior part of the tail at the junction of a tergite on batches of 20-40 shrimp. Shrimp were returned to seawater ( 20 shrimp of the same batch per tank) and fed daily with freshly opened mussels. Dead shrimp were counted twice a day during 11 consecutive days.

\subsection{In vitro bacterial assay}

Both Vibrio were grown overnight at $20^{\circ} \mathrm{C}$ in trypsin-casein-soya liquid medium (TCS, AES Laboratoire) adjusted to sea water ionic strength by adding $\mathrm{NaCl} 1 \%$. M. Iysodeikticus and $\mathrm{E}$. coli were grown overnight at $37^{\circ} \mathrm{C}$ in Luria-Bertani broth (Becton Dickinson). For each bacterium, one aliquot of $50 \mu \mathrm{l}$ was used to restart a new culture in $10 \mathrm{ml}$ of the respective media. Growth was monitored by 
measuring the $\mathrm{OD}$ at $600 \mathrm{~nm}$ and cultures were stopped at 0.1-0.2 absorbance unit to obtain bacteria in exponential growth phase, and adjusted to $1.25 \times 10^{6}$ bacteria per ml. Such quantities were more precisely determined with a Facs-Calibur flow cytometer (Becton-Dickinson) equipped with an aircooled argon laser (488 $\mathrm{nm}$ ) using SYBR-green I (Molecular Probes) bacterial cell stain according to Marie et al [34].

In vitro growth inhibition assay consisted in serial doubling dilutions of the synthetic fragments in $20 \mu \mathrm{l}$ of sterile water in 96-flat well microtiter plate. Each well received $80 \mu \mathrm{l}$ of bacteria suspension containing $10^{5}$ bacteria. Bacteria growth was evaluated by $D_{600}$ (Multiskan Titertek) after $24 \mathrm{~h}$ incubation at either $20^{\circ} \mathrm{C}$ or $37^{\circ} \mathrm{C}$. MIC corresponded to the first well with absorbance not different from culture medium. MBC corresponded to the lowest peptide concentration that prevented any CFU after plating $50 \mu \mathrm{l}$ from the wells onto corresponding nutrient agar.

\section{Results}

\subsection{Solution structure of mytilin}

Assignment - Oxidative folding of linear mytilin gave the folded mytilin with $a \approx 90 \%$ yield. After its HPLC purification, its structural study was carried out by NMR. In the $1 \mathrm{H}$ NMR spectrum of mytilin recorded in water at $22^{\circ} \mathrm{C}$ and $\mathrm{pH} 3.3$, amide signals are in the 9.8-6.8 ppm range suggesting highly constrained structure (Fig. 1). The identification and assignment of all the spin systems of mytilin was obtained by analysis and comparison of DQF-COSY, TOCSY, and NOESY spectra according to the strategy described by Wüthrich [29]. Atypical chemical shifts were observed for the $\mathrm{K} 7 \mathrm{H} \alpha$ proton (2.77

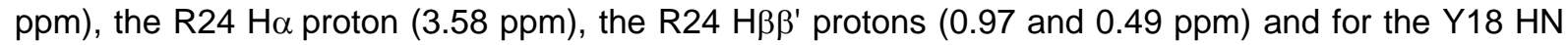
(6.89 ppm) which appeared particularly up field shifted. In contrast, the S20 Ho proton was downfield shifted (5.67 ppm). The NOESY experiments exhibited several successive and strong NN and $\alpha i-\beta i+3$ NOEs as well as $\mathrm{H} \alpha-\mathrm{HN}$ sequential NOEs suggesting the presence of helical and of $\beta$-stranded structures, respectively.

Mytilin structure - To calculate the mytilin solution structure with XPLOR, 474 NOE-derived distances and 46 dihedral constraints were used as input. The global fold of mytilin consists of an $\alpha$-helix (residues from 2 to 13) and of a two-stranded $\beta$-sheet (residues from 17 to 23 for the strand I, and 26 to 32 for the strand II) tightly linked together by four regularly separated disulfide bonds whose arrangement has been identified as 2-27, 6-29, 10-31 and 15-34 on the basis of specific NOEs for each of them (for example $d_{\alpha \alpha}$ for the 15-34 disulfide bond) (Fig. 2). Loop 1 and loop 2 link the helix with the strand I, and the strand I with the strand II, respectively. Statistical analysis of the four disulfide bridges showed that they have mean $\chi 3$ angle values of $130.9 \pm 6.3^{\circ}, 80.3 \pm 3.4^{\circ}, 98.0 \pm 5.2^{\circ}$ and $110.9 \pm 0.6^{\circ}$, respectively, all in the $\pm 90 \pm 45^{\circ}$ value measured for classical conformations of disulfide bridges [35]. The egg-shaped structure is about $40 \AA$ and $19-23 \AA$.

As a result, the mytilin structure is well-defined and the pair wise mean rmsd value for the superimposition of the backbone atoms of the 20 best conformers was $0.33 \pm 0.09 \AA$. The distribution in the Ramachandran plot of all residues (except for the glycines) indicates their quality: $82.8 \%$ are located in the most favoured regions, $17.2 \%$ in the additional allowed regions [32].

The helix is particularly amphipathic. Its solvent exposed residues (S4, R5, K7, G8, H9, R11 and R13) with the S1 and R14 residues give rise to a first hydrophilic cluster. A second one is composed of the R24, G25 and R26 residues located in the loop 2. In contrast, the internal side of the helix belongs to the hydrophobic core, which mainly consists of the helix $\beta$-sheet interface and of the four N-terminal cysteines (C2, C6, C10 and C15). The four C-terminal cysteines (C27, C29, C31 and C34) are more solvent exposed and along with the Y23, L22, V21, V19, Y18, Y17 Y28 and L32 side chains give rise to a large hydrophobic cluster. Consequently, the ovoid structure of mytilin displays an amphipathic feature which could be responsible for its antimicrobial activities.

Comparison of mytilin and MGD-1 structures highlights similar global folds with comparable disulfide bond patterns (Fig. 2). However, despite an identical connectivity, the 2-27 disulfide bond is different to the C4-C25 equivalent disulfide bond in MGD-1 [16]. Indeed, in mytilin the C27 is located on the strand 
II instead of on the strand I for the C25 of MGD-1. Consequently, only the strand II of mytilin is constrained by the four disulfide bonds and the resulting $\beta$-sheet structures significantly differ in the two molecules. Stabilized by 9 hydrogen bonds, instead of 6 for MGD-1, the mytilin $\beta$-sheet ( $\beta$-hairpin) is more regular and its loop (loop 2) shorter than the corresponding loop of MGD-1 (loop 3). Interestingly, the mytilin loop sequence (Y23RGR26) and the MGD-1 loop sequence (G26GWHRLR32) contain two arginine residues spaced by one residue. These two arginines belong to the hydrophilic clusters.

\subsection{Sequences and structure of fragments}

Four peptides were designed from the sequence including the loop 2 of the mytilin (Fig. 2 and Table 1). In order to maintain the three-dimensional structure of such peptides as close as possible to the original $\beta$-hairpin conformation, selected amino acids were substituted for cysteines to constrain the designed peptides with one disulfide bond (L22 for the C6C peptide) and with two disulfide bonds (S20 and L22 for the C10C peptide). The replacement of cysteines C27 and C29 by serines (S10S peptide) prevented the formation of disulfide bond, S10S being supposed to adopt a random coil conformation in solution. Additional positive charges were included in C10C by replacing Y23 and G25 by lysines (C10C+ peptide).

The structural study of the $\mathrm{C} 6 \mathrm{C}$ and $\mathrm{C} 10 \mathrm{C}$ cyclic peptides were also carried out. It appeared that the C6C does not adopt a well-defined structure. In contrast, the $\mathrm{C} 10 \mathrm{C}$ solution structure consists of a well-defined $\beta$-hairpin stabilized by the $\mathrm{C} 1-\mathrm{C} 10$ and the $\mathrm{C} 3-\mathrm{C} 8$ disulfide bonds (Fig. 3) which well mimics the protegrin structure, a 18-residue antimicrobial peptide [36].

In addition, $1 \mathrm{H}$ NMR was used to monitor the $\mathrm{C} 10 \mathrm{C}$ peptide stability at $20^{\circ} \mathrm{C}$ in a $2 \mathrm{mM}$ aqueous solution. Its NMR spectrum was unchanged, both at pH 7.6 and 4.6 and for at least 15 days. In presence of $650 \mathrm{mM}$ of $\mathrm{NaCl}$, to mimic the internal marine invertebrate ionic strength, most of the peptide precipitated indicating a significant decrease of its solubility in high ionic strength medium. However, replacing the salty water by fresh one resulted in the dissolution of the precipitate, and the initial NMR spectrum was recovered indicating that its chemical structure remained unchanged (data not shown).

\subsection{Difference of susceptibility between $L$. japonicus and $P$. serratus}

The two marine shrimp, $L$. japonicus and $P$. serratus were submitted to contamination by purified WSSV. Both were susceptible to the virus when injected into the tail muscle (Fig. 4). L. japonicus, the normal host of WSSV, appeared more sensitive as all the injected shrimp died within 3.5 days whereas it took 6 days to kill all the $P$. serratus. Infection per os by infected carcasses, the main route of infection between $L$. japonicus, resulted in $100 \%$ mortality of $L$. japonicus within 9 days. On the opposite, none of the $P$. serratus died when eating carcasses containing WSSV, revealing they cannot be infected by oral route. Consequently, further mortalities observed in $P$. serratus challenged with WSSV will never resulted from secondary infection by cannibalism on dead shrimp.

\subsection{Protective effect of the fragments}

Purified WSSV was incubated during $30 \mathrm{~min}$ at $20^{\circ} \mathrm{C}$ with $50 \mu \mathrm{M}$ of $\mathrm{C} 6 \mathrm{C}, \mathrm{C} 10 \mathrm{C}, \mathrm{C} 10 \mathrm{C}+$ or S10S. The resulting washed virus suspensions were injected to $P$. serratus and the mortalities recorded during 7 days. Only the fragment C10C strongly reduced the mortality due to WSSV (Fig. 5). The three other fragments, C6C, C10C+ and S10S, did not modify the kinetics of mortality, and all the shrimp died within 3-3.5 days, in kinetics similar as after injection of untreated virus. One new injection of untreated WSSV suspension was performed on day 7 . Whatever the shrimp were previously injected with C10Ctreated WSSV or with TN alone, they all died within 3.5-4 days with similar kinetics. 


\subsection{Dose effect}

Comparative dose-effects between the synthetic mytilin and the $\mathrm{C} 10 \mathrm{C}$ fragment was performed on $P$. serratus by injecting WSSV previously incubated during $30 \mathrm{~min}$ at $20^{\circ} \mathrm{C}$ with increasing concentrations of peptides. In both cases, $100 \%$ survival was obtained but with different concentrations: $50 \mu \mathrm{M}$ for mytilin and $100 \mu \mathrm{M}$ for C10C (Fig. 6). From the dose-effect curves, bigger difference was measured when considering the concentrations inducing $50 \%$ protection (IC50). With an IC50 value of $7 \mu \mathrm{M}$, mytilin is 6-folds more potent than the C10C fragment (IC50 $=45 \mu \mathrm{M})$.

\subsection{Kinetics of activity onto WSSV}

Using the concentration of $100 \mu \mathrm{M}, \mathrm{C} 10 \mathrm{C}$ was incubated with WSSV during 1 to 60 min before washing and being injected to $P$. serratus. Figure 7 showed that 1 min of contact was enough to interfere with the virus in such a way only $40 \%$ of the shrimp died within 3.5 days. As soon as after 10 min of contact, about $90 \%$ of the shrimp survived and all the shrimp were protected when the virus was incubated during 30 min.

\subsection{Antibacterial activities}

In vitro growth inhibition was observed with C10C (Table 2). Considering the active concentrations, $V$. splendidus appeared 16 times more sensitive than $V$. anguillarum (MIC $0.125 \mathrm{mM}$ and $2 \mathrm{mM}$, respectively). No difference in sensitivity was noticed between the two Gram positive bacteria, with MIC values half the one of $V$. anguillarum. Exact numbers of bacteria present in the wells were determined by flow cytometer analysis and the active concentrations reported to the number of target bacteria. Considering the minimum numbers of molecules per bacteria capable to kill the bacteria, results were slightly different (Table 2 ). $V$. splendidus was still the most sensitive with the lowest number of $4.2 \times 10^{10}$ molecules per bacteria, but comparable to $E$. coli $\left(5.5 \times 10^{10}\right)$. On the contrary, $M$. lysodeikticus required 8.5 times more molecules, whereas the value for $V$. anguillarum was not reached in the assay and evaluated as superior to $53.5 \times 10^{10}$.

\section{Discussion}

Mytilin-B (34 amino acid residues) and MGD-1 (39 amino acid residues) sequences share $36 \%$ of identity. The two sequences are devoid of negatively charged residues. In contrast to MGD-1 which contains 2 proline residues, the mytilin sequence is proline-free. Their sequence alignment displays three two-residue deletions, one two-residue insertion and highlights the alignment of 7 out of the 8 cysteines (C2, C6, C10, C15, C29, C31 and C34) as well as of 4 arginines (R14, R24, R26, R33) (Fig. 2).

Mytilin was synthesized and, in contrast to MGD-1 [16], its oxidative folding was highly productive. The solution structure revealed a fold and disulfide bond connectivity comparable to that of MGD-1. The C2-C27 disulfide bond, corresponding to the C4-C25 disulfide bond of MGD-1, is different since C27 belongs to the strand II instead of the strand I for C25 (Fig. 2). The mytilin structure significantly differs from the MGD-1 structure mainly by the shorter $\mathrm{N}$-terminal part and by the more extended $\beta$-hairpin probably due to the fact that the C27, C29, C31 and C34 cysteines involved in the 4 disulfide bonds are all located on the strand II. It is worth noting that by using the Motif-search online software (http://motif.genome.jp/MOTIF2.html), the full mytilin cysteine pattern motif $(C-x(3)-C-x(3)-C-x(4)-C-$ $\mathrm{x}(11)-\mathrm{C}-\mathrm{x}-\mathrm{C}-\mathrm{x}-\mathrm{C}-\mathrm{x}(2)-\mathrm{C}$.) was not found in any protein from the Swiss-prot database.

For mytilin, hydrophilic and hydrophobic areas account for $63 \%$ and $37 \%$, respectively, a ratio very close to that of MGD-1 (64\% and 36\%). The helix and the loop 1 of mytilin give rise to the two main hydrophilic clusters whereas the hydrophobic cluster arises mainly from the $\beta$-sheet. Interestingly, the loop 2 linking the two $\beta$-strands displays two conserved arginines, R24 and R26 for mytilin, and R30 and R32 for the equivalent loop 3 of MGD-1.

The peptides designed on the basis of the $\beta$-hairpin structure of mytilin, were of various lengths and more or less constrained. Devoid of disulfide bond, the S10S peptide was used as a peptide supposed 
to adopt a random coil conformation while with one disulfide bond the $\mathrm{C} 6 \mathrm{C}$ peptide was macrocyclic. In contrast, with its two disulfide bonds, the $\mathrm{C} 10 \mathrm{C}$ peptide was shown to mimic the $\beta$-hairpin structure of mytilin.

The normal host of WSSV is Litopenaeus sp. with usual route of infestation being by cannibalism on infected carcasses [37]. However, WSSV is not restricted to the Litopenaeus family, but also capable of developing into several marine and freshwater crustaceans, including the shrimp Palaemon adspersus [38, 39]. We confirmed our previous observation on the route of penetration into Palaemon sp. which cannot be per os, but required direct injection to induce mortality [40]. One can hypothesize that WSSV has a long evolutionary relationship with the Litopenaeus family resulting in close hostpathogen adaptation, which is not the case considering the Palaemon family being far more recent in evolution with less than 100 million years, compared to the 437 million years for the Litopenaeus family [41].

To check for antiviral activity of mussel AMPs necessitates using exotic virus-host model as no virus were reported pathogenic for Mytilus, even if viruses were recently suspected to be responsible for gill disease [42]. Only in oyster, Crassostrea gigas, a herpes virus (OsHV-1) was found associated with sporadic mortality among larvae and spat $[43,44]$. Meanwhile, despite numerous efforts to in vitro growth crustacean viruses, only IHHNV from peanaeid shrimp was reported as capable of multiplication in the carp, Cyprinus carpio cell line [45], and a nodavirus from freshwater prawn, Macrobrachium rosenbergii (MrNv) developed partially in the fish Channa striatus SSN1 cell line (unpublished data). The only attempt to establish an autologous model was with the baculo-like virus from L. japonicus infecting primary shrimp lymphoid cell cultures [46]. Consequently, WSSV used in the present study was purified at a time from contaminated Penaeus monodon carcasses, with no possibility to adjust the concentration of infectious particles.

Our first assay to inhibit WSSV infestation of shrimp was done with synthetic mytilin and IC50 value was established at $5 \mu \mathrm{M}$ [3]. Assays with a 13 amino acid peptide (fragment 15-27) designed by analogy with the active moiety of MGD-1 failed to reveal any antiviral activity. In the present study, shorter fragment of 10 amino acids (C10C) was able to prevent mortality due to WSSV with an IC50 value of $45 \mu \mathrm{M}$. Comparable increase in efficient doses between mature molecules and truncated fragments, but related to the antibacterial capability, was also observed for mussel defensin [18], and cecropin (from the silk moth Hyalophora cecropia) [47], underlining the importance of the rest of the molecule to display full activity. $\mathrm{C} 10 \mathrm{C}$ is constrained by two disulfide bonds whereas fragment 15-27 and fragment $\mathrm{C6C}$ were most probably macrocyclic as constrained by only one disulfide bond. Replacing the four cysteines of $\mathrm{C} 10 \mathrm{C}$ by four serines resulted in a random coil conformation of S10S which did not possess any antiviral or antibacterial activities, confirming our previous data on MGD-1derived peptides revealing that antibacterial and antifungal activities [18] as well as anti-protozoa and antiviral activities [2] were strictly dependent on bridging. Exception was reported for tacheplysin-1 in which deletion of all cysteines retains antimicrobial activity [48].

C10C was designed to mimic the $\beta$-hairpin structure of mytilin and it was the only fragment inhibiting virus infection and bacteria growth. Protegrin-1 (from porcine neutrophils) [49], and tachyplesin-1 and 2 (from horseshoe crab Tachypleus tridentatus) and polyphemusin-1 (from horseshoe crab Limulus polyphemus) [50] also presented $\beta$-hairpin structures responsible for anti bacterial/fungi/virus activities. As depicted in Figure 8, the structures are comparable, with a tyrosine $(Y)$ and a valine $(V)$ preceding the two distal cysteines (C). In addition, $\beta$-turns are always positively charged and adjacent to hydrophobic clusters. Putative influence of positive charges was studied on antibacterial activity replacing arginines with non-ionisable citrullines in defensin synthetic fragments. As a consequence the pl was lowered and the antibacterial activity was almost completely lost [18]. In contrast, increasing the positive charges by replacing naturally occurring residues with lysines correlated with higher activity, a phenomenon also observed on cecropin [47]. One can hypothesized that more positive charges resulted in stronger binding of the peptide to the negatively charged prokaryote membrane, as reported for magainin (from the African clawed frog Xenopus laevis) [51]. Meanwhile, in the present work, it was not possible to increase the antibacterial activity of $\mathrm{C} 10 \mathrm{C}$ by addition of 2 positive charges $(\mathrm{C} 10 \mathrm{C}+)$ and the anti viral activity was totally lost. On the other hand, $60 \%$ of the infectious capacity of WSSV was inhibited after less than 1 min of contact with the peptide, a rapid interaction which argues in favor of the involvement of electrostatic interactions in the inhibitory process.

Inhibition of WSSV (this work) and HIV-1 infections [2] have been obtained only when the viruses were incubated with the peptides before being in contact with the cells, suggesting a direct binding of the peptides onto the virus envelopes. Several works are in agreement with such peptide-virus interactions: (i) cell fusion, growth and protein synthesis mediated by herpes simplex virus 1 were completely inhibited by pre-incubation of the virus with analogues of mellitin (from honeybee's Apis 
melilfera venom) [52]; (ii) synthetic derivatives of magainins inhibited herpes simplex virus 1 plaqueforming units when pretreated with the peptides prior to inoculation onto Vero monolayers (kidney epithelial cells isolated from African green monkey) [53]; (iii) direct disruption of the viral envelope by cecropin and one synthetic analogue is responsible for the inhibition of several fish viruses [54]; (iiii) human defensin retrocyclin 2 inhibited influenza virus infection by blocking membrane fusion [55].

Due to their high pharmaceutical potential, numerous assays are currently performed using macrocyclic template-bound $\beta$-hairpin mimetic peptides (see [56] and [57] for examples), some of them being in phase III clinical trials, such is iseganan, an analogue of protegrin-1 [58]. Meanwhile, among the tens of thousands biologically active natural agents isolated from marine organisms, excluding vertebrates (see [59] for review), only some hundreds displayed anti-infective capabilities and less than 150 are antivirus [60]. They have been isolated from blue green algae, seaweeds, sponges, marine fungi, etc, the vast majority being non-genetically coded. Actually, the horseshoe crabs, Limulus polyphemus and Tachypleus tridentatus, and the mussel, Mytilus galloprovincialis, are the only marine invertebrates with reported antiviral peptides, even if mussel closely-related threedimensional structure of oyster defensin [13] suggested similar biological activities.

The $\beta$-hairpin conformation of $\mathrm{C} 10 \mathrm{C}$ was stable in solution at room temperature for at least two weeks. Adding $\mathrm{NaCl}$ resulted in $\mathrm{C} 10 \mathrm{C}$ precipitation, but identical hairpin structure was recovered when decreasing the salt content. Such capacity to cross salty environments without damage might be of great interest if $\mathrm{C} 10 \mathrm{C}$ has to be added to marine invertebrate diet, for instance. After being absorbed with the food pellets, the peptide might be precipitated by the elevated ionic strength of the shrimp body fluids. Meanwhile, hypothesizing up to $90 \%$ of the peptide being precipitated, the remaining soluble concentration might be high enough to retain biological activities. In our in vitro stability/solubility assays performed by NMR with a $2 \mathrm{mM}$ sample of C10C, 90\% precipitation will leave about $200 \mu \mathrm{M}$ soluble peptide, a value higher than the MIC/MBC of $125 \mu \mathrm{M}$ measured for $V$. splendidus and the IC50 value of $45 \mu \mathrm{M}$ measured for WSSV, both in salty medium. In addition, the precipitate may serve as reservoir to maintain constant the soluble concentration. In conclusion, the C10C mytilin fragment corresponding to the $\beta$-hairpin domain precipitates in salty water, recovered original structure when lowering the salt content and appeared to be soluble enough in high ionic strength environment to express anti viral/bacterial activities. As of small size and easy to synthesize, its biotechnology development might be considered.

\section{Acknowledgments}

The authors would like to thank Valérie Bonnichon and Idalia Hernandez for conducting repetitive virus preparations and to Patrice Got for flow cytometer analysis. Vibrio splendidus LGP32 was a gift from Frédérique Le Roux, IFREMER-La Tremblade-France. This work was partly supported by the European Community programme FOOD-CT-2005-007103 IMAQUANIM.

\section{References}

[1] Murakami T, Niwa M, Tokunaga F, Miyata T, Iwanaga S. Direct virus inactivation of tachyplesin I and its isopeptides from horseshoe crab hemocytes. Chemotherapy 1991;37:327-34.

[2] Roch P, Beschin A, Bernard E. Antiprotozoan and Antiviral Activities of Non-cytotoxic Truncated and Variant Analogues of Mussel Defensin. Evid Based Complement Alternat Med 2004;1:167-74.

[3] Dupuy JW, Bonami JR, Roch P. A synthetic antibacterial peptide from Mytilus galloprovincialis reduces mortality due to white spot syndrome virus in palaemonid shrimp. J Fish Dis 2004;27:57-64.

[4] Zambon RA, Nandakumar M, Vakharia VN, Wu LP. The Toll pathway is important for an antiviral response in Drosophila. Proc Natl Acad Sci U S A 2005;102:7257-62.

[5] Huang HW. Action of antimicrobial peptides: two-state model. Biochemistry 2000;39:8347-52.

[6] Mitta G, Vandenbulcke F, Roch P. Original involvement of antimicrobial peptides in mussel innate immunity. FEBS Lett 2000;486:185-90.

[7] Charlet M, Chernysh S, Philippe H, Hetru C, Hoffmann JA, Bulet P. Innate immunity. Isolation of several cysteine-rich antimicrobial peptides from the blood of a mollusc, Mytilus edulis. J Biol Chem 1996;271:21808-13. 
[8] Jenny MJ, Ringwood AH, Lacy ER, Lewitus AJ, Kempton JW, Gross PS, et al. Potential indicators of stress response identified by expressed sequence tag analysis of hemocytes and embryos from the American oyster, Crassostrea virginica. Mar Biotechnol (NY) 2002;4:81-93.

[9] Gueguen Y, Cadoret JP, Flament D, Barreau-Roumiguiere C, Girardot AL, Garnier J, et al. Immune gene discovery by expressed sequence tags generated from hemocytes of the bacteriachallenged oyster, Crassostrea gigas. Gene 2003;303:139-45.

[10] Tanguy A, Guo X, Ford SE. Discovery of genes expressed in response to Perkinsus marinus challenge in Eastern (Crassostrea virginica) and Pacific (C. gigas) oysters. Gene 2004;338:121-31.

[11] Cunningham C, Hikima J, Jenny MJ, Chapman RW, Fang GC, Saski C, et al. New resources for marine genomics: bacterial artificial chromosome libraries for the Eastern and Pacific oysters (Crassostrea virginica and C. gigas). Mar Biotechnol (NY) 2006;8:521-33.

[12] Seo JK, Crawford JM, Stone KL, Noga EJ. Purification of a novel arthropod defensin from the American oyster, Crassostrea virginica. Biochem Biophys Res Commun 2005;338:1998-2004.

[13] Gueguen Y, Herpin A, Aumelas A, Garnier J, Fievet J, Escoubas JM, et al. Characterization of a defensin from the oyster Crassostrea gigas. Recombinant production, folding, solution structure, antimicrobial activities, and gene expression. J Biol Chem 2006;281:313-23.

[14] Song L, Xu W, Li C, Li H, Wu L, Xiang J, et al. Development of expressed sequence tags from the Bay Scallop, Argopecten irradians irradians. Mar Biotechnol (NY) 2006;8:161-9.

[15] Gonzalez M, Gueguen Y, Desserre G, de Lorgeril J, Romestand B, Bachere E. Molecular characterization of two isoforms of defensin from hemocytes of the oyster Crassostrea gigas. Dev Comp Immunol 2007;31:332-9.

[16] Yang YS, Mitta G, Chavanieu A, Calas B, Sanchez JF, Roch P, et al. Solution structure and activity of the synthetic four-disulfide bond Mediterranean mussel defensin (MGD-1). Biochemistry 2000;39:14436-47.

[17] Cornet B, Bonmatin JM, Hetru C, Hoffmann JA, Ptak M, Vovelle F. Refined three-dimensional solution structure of insect defensin A. Structure 1995;3:435-48.

[18] Romestand B, Molina F, Richard V, Roch P, Granier C. Key role of the loop connecting the two beta strands of mussel defensin in its antimicrobial activity. Eur J Biochem 2003;270:2805-13.

[19] van Hulten MC, Witteveldt J, Peters S, Kloosterboer N, Tarchini R, Fiers M, et al. The white spot syndrome virus DNA genome sequence. Virology 2001;286:7-22.

[20] Gay M, Berthe FC, Le Roux F. Screening of Vibrio isolates to develop an experimental infection model in the Pacific oyster Crassostrea gigas. Dis Aquat Organ 2004;59:49-56.

[21] Rance M, Sorensen OW, Bodenhausen G, Wagner G, Ernst RR, Wuthrich K. Improved spectral resolution in cosy $1 \mathrm{H}$ NMR spectra of proteins via double quantum filtering. Biochem Biophys Res Commun 1983;117:479-85.

[22] Derome AE, Williamson MP. Rapid-pulsing artifacts in doube-quantum-filtered COSY. J Magn Reson 1990;88:177-85.

[23] Bax A, Davis GD. MLEV-17-based two-dimensional homonuclear magnetization transfer spectroscopy. J Magn Reson 1985;65:355-60.

[24] Rance M. Improved techniques for homonuclear rotating-frame and isotropic mixing experiments. J Magn Reson 1987;74:557-64.

[25] Macura S, Huang Y, Sutter D, Ernst RR. Two-dimensional chemical exchange and crossrelaxation spectroscopy of coupled nuclear spins. J Magn Reson 1981;43:259-81.

[26] Marion D, Ikura M, Tschudin R, Bax A. Rapid recording of 2D NMR spectra without phase cycling. Application to the study of hydrogen exchange in proteins. J Magn Reson 1989;85:393-9.

[27] Piotto M, Saudek V, Sklenar V. Gradient-tailored excitation for single-quantum NMR spectroscopy of aqueous solutions. J Biomol NMR 1992;2:661-5.

[28] Pons JL, Malliavin TE, Delsuc MA. Gifa V.4: a complete package for NMR data set processing. J Biolmol NMR 1996;8:445-52.

[29] Wüthrich K. NMR of Proteins and Nucleic Acids. New York: John Wiley \& sons, 1986.

[30] Rice LM, Brunger AT. Torsion angle dynamics: reduced variable conformational sampling enhances crystallographic structure refinement. Proteins 1994;19:277-90.

[31] Nilges M, Clore GM, Gronenborn AM. Determination of three-dimensional structures of proteins from interproton distance data by hybrid distance geometry-dynamical simulated annealing calculations. FEBS Lett 1988;229:317-24.

[32] Laskowski RA, Rullmannn JA, MacArthur MW, Kaptein R, Thornton JM. AQUA and PROCHECK-NMR: programs for checking the quality of protein structures solved by NMR. J Biomol NMR 1996;8:477-86.

[33] Frishman D, Argos P. Knowledge-based protein secondary structure assignment. Proteins 1995;23:566-79. 
[34] Marie D, Partensky F, Jacquet S, Vaulot D. Enumeration and Cell Cycle Analysis of Natural Populations of Marine Picoplankton by Flow Cytometry Using the Nucleic Acid Stain SYBR Green I. Appl Environ Microbiol 1997;63:186-93.

[35] Srinivasan N, Sowdhamini R, Ramakrishnan C, Balaram P. Conformations of disulfide bridges in proteins. Int J Pept Protein Res 1990;36:147-55.

[36] Aumelas A, Mangoni M, Roumestand C, Chiche L, Despaux E, Grassy G, et al. Synthesis and solution structure of the antimicrobial peptide protegrin-1. Eur J Biochem 1996;237:575-83.

[37] Soto MA, Shervette VR, Lotz JM. Transmission of white spot syndrome virus (WSSV) to Litopenaeus vannamei from infected cephalothorax, abdomen, or whole shrimp cadaver. Dis Aquat Organ 2001;45:81-7.

[38] Lo C, Ho C, Peng S, Chen C, Hsu H, Chiu Y, et al. White Spot Syndrome Baculovirus (WSBV) detected in cultured and captured shrimp, crabs and other arthropods. Dis Aquat Organ 1996;27:21525.

[39] Corbel V, Zuprizal, Shi Z, Huang C, Sumartono, Arcier JM, et al. Experimental infection of European crustaceans with White Spot Syndrome Virus (WSSV). J Fish Dis 2001;24:377-82.

[40] Di Leonardo VA, Bonnichon V, Roch P, Parrinello N, Bonami JR. Comparative WSSV infection routes in the shrimp genera Marsupenaeus and Palaemon. J Fish Dis 2005;28:565-9.

[41] Porter ML, Perez-Losada M, Crandall KA. Model-based multi-locus estimation of decapod phylogeny and divergence times. Mol Phylogenet Evol 2005;37:355-69.

[42] Smolarz K, Wolowicz M, Stachnik M. First record of the occurrence of "gill disease" in Mytilus edulis trossulus from the Gulf of Gdansk (Baltic Sea, Poland). J Invertebr Pathol 2006;93:207-9.

[43] Davison AJ, Trus BL, Cheng N, Steven AC, Watson MS, Cunningham C, et al. A novel class of herpesvirus with bivalve hosts. J Gen Virol 2005;86:41-53.

[44] Olicard C, Didier Y, Marty C, Bourgougnon N, Renault T. In vitro research of anti-HSV-1 activity in different extracts from Pacific oysters Crassostrea gigas. Dis Aquat Organ 2005;67:141-7.

[45] Loh PC, Lu Y, Brock JA. Growth of the penaeid shrimp virus infectious hypodermal and hematopoietic necrosis virus in a fish cell line. J Virol Methods 1990;28:273-80.

[46] Tapay LM, Lu Y, Gose RB, Nadala EC, Jr., Brock JA, Loh PC. Development of an in vitro quantal assay in primary cell cultures for a non-occluded baculo-like virus of penaeid shrimp. J Virol Methods 1997;64:37-41.

[47] Shin SY, Lee KW, Kim Y, Kim JI, Hahm KS, Kang SW. Structure-antibacterial activity relationship of cecropin A derivatives. Protein Pept Lett 2002;9:487-93.

[48] Ramamoorthy A, Thennarasu S, Tan A, Gottipati K, Sreekumar S, Heyl DL, et al. Deletion of all cysteines in tachyplesin I abolishes hemolytic activity and retains antimicrobial activity and lipopolysaccharide selective binding. Biochemistry 2006;45:6529-40.

[49] Tamamura H, Murakami T, Horiuchi S, Sugihara K, Otaka A, Takada W, et al. Synthesis of protegrin-related peptides and their antibacterial and anti-human immunodeficiency virus activity. Chem Pharm Bull (Tokyo) 1995;43:853-8.

[50] Masuda M, Nakashima H, Ueda T, Naba H, Ikoma R, Otaka A, et al. A novel anti-HIV synthetic peptide, T-22 ([Tyr5,12,Lys7]-polyphemusin II). Biochem Biophys Res Commun 1992;189:845-50.

[51] Matsuzaki K, Nakamura A, Murase O, Sugishita K, Fujii N, Miyajima K. Modulation of magainin 2-lipid bilayer interactions by peptide charge. Biochemistry 1997;36:2104-11.

[52] Baghian A, Jaynes J, Enright F, Kousoulas KG. An amphipathic alpha-helical synthetic peptide analogue of melittin inhibits herpes simplex virus-1 (HSV-1)-induced cell fusion and virus spread. Peptides 1997;18:177-83.

[53] Egal M, Conrad M, MacDonald DL, Maloy WL, Motley M, Genco CA. Antiviral effects of synthetic membrane-active peptides on herpes simplex virus, type 1 . Int $\mathrm{J}$ Antimicrob Agents 1999;13:57-60.

[54] Chiou PP, Lin CM, Perez L, Chen TT. Effect of cecropin B and a synthetic analogue on propagation of fish viruses in vitro. Mar Biotechnol (NY) 2002;4:294-302.

[55] Leikina E, Delanoe-Ayari H, Melikov K, Cho MS, Chen A, Waring AJ, et al. Carbohydratebinding molecules inhibit viral fusion and entry by crosslinking membrane glycoproteins. Nat Immunol 2005;6:995-1001.

[56] Shankaramma SC, Athanassiou Z, Zerbe O, Moehle K, Mouton C, Bernardini F, et al. Macrocyclic hairpin mimetics of the cationic antimicrobial peptide protegrin I: a new family of broadspectrum antibiotics. Chembiochem 2002;3:1126-33.

[57] DeMarco SJ, Henze H, Lederer A, Moehle K, Mukherjee R, Romagnoli B, et al. Discovery of novel, highly potent and selective beta-hairpin mimetic CXCR4 inhibitors with excellent anti-HIV activity and pharmacokinetic profiles. Bioorg Med Chem 2006;14:8396-404. 
[58] Giles FJ, Rodriguez R, Weisdorf D, Wingard JR, Martin PJ, Fleming TR, et al. A phase III, randomized, double-blind, placebo-controlled, study of iseganan for the reduction of stomatitis in patients receiving stomatotoxic chemotherapy. Leuk Res 2004;28:559-65.

[59] Donia M, Hamann MT. Marine natural products and their potential applications as antiinfective agents. Lancet Infect Dis 2003;3:338-48.

[60] Tziveleka LA, Vagias C, Roussis V. Natural products with anti-HIV activity from marine organisms. Curr Top Med Chem 2003;3:1512-35. 
Table 1 - Amino acid sequences of mytilin and selected fragments with their respective net charge and MW.

\begin{tabular}{|c|c|c|c|c|}
\hline & & 10 & 20 & \\
\hline Fragments & $\mathrm{C} 6 \mathrm{C}$ & C10C & $\mathrm{C} 10 \mathrm{C}+$ & S10S \\
\hline aa sequence & AcCYRGRC $\mathrm{NH}_{2}$ & $\underbrace{\mathrm{AcCVCYRGRCYC} \mathrm{NH}_{2}}$ & $\underbrace{\mathrm{AcCVCKRKRCYC} \mathrm{NH}_{2}}$ & AcSVSYRGRSYS NH \\
\hline Net charge & $2+$ & $2+$ & $4+$ & $2+$ \\
\hline MW & 795 & 1,261 & 1,298 & 1,202 \\
\hline
\end{tabular}

The grey box indicated the location of loop 2 from where the fragments were derived.

Lines joining the Cys represent non-natural disulfide bond to maintain the 3D structure similar to that in the complete peptide. 
Table 2 - Antibacterial activity of mytilin synthetic fragment C10C.

\begin{tabular}{lcccc}
\hline \multicolumn{1}{c}{ Bacteria } & Activity & $\begin{array}{c}\text { Molarity } \\
(\mathrm{mM})\end{array}$ & $\begin{array}{c}\text { Number of bacteria } \\
\text { per well }\left(\times 10^{-5}\right)^{\star}\end{array}$ & $\begin{array}{c}\text { Number of molecules } \\
\text { per bacteria }\left(\times 10^{-10}\right)\end{array}$ \\
\hline Gram negative & & & & \\
Vibrio splendidus LGP32 & MIC & 0.125 & 1.76 & 4.2 \\
Vibrio anguillarum & MBC & 0.125 & 1.76 & 4.2 \\
Gram positive & MIC & 2 & 2.24 & 53.5 \\
Micrococcus lysodeikticus & MBC & $>2$ & 2.24 & 53.5 \\
Escherichia coli & MIC & 1 & & 18.0 \\
& MBC & 2 & 3.30 & 36.0 \\
& MIC & 1 & 3.30 & 2.7 \\
& MBC & 2 & 21.60 & 5.5 \\
\hline
\end{tabular}

* Evaluated by flow cytometer analysis. 


\section{Figures}
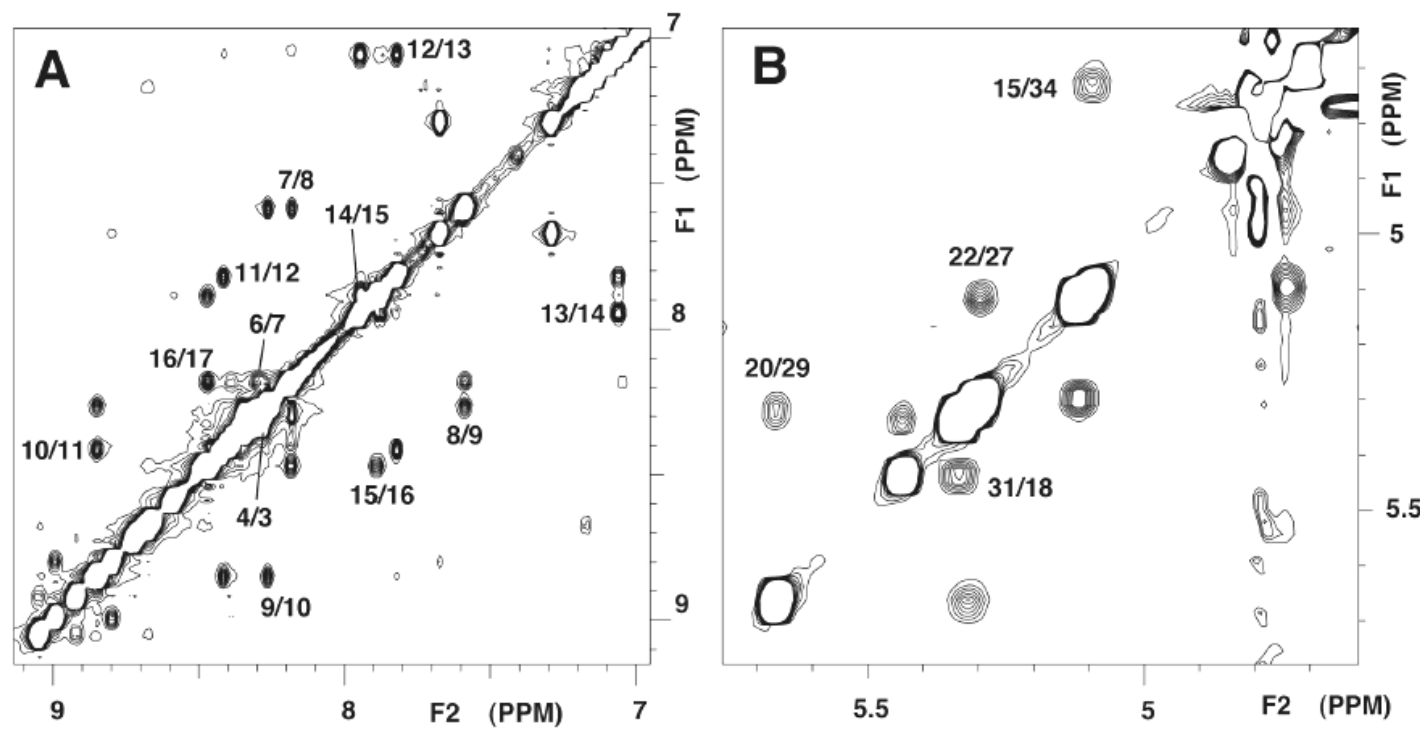

C

10

20

30

S C A S R C K G H C RAR R C G Y Y V S V L Y R G R C Y C K C L R C

$$
\begin{aligned}
& d_{\mathrm{NN}}(i, i+1) \\
& d_{\alpha \mathrm{N}}(i, i+1) \\
& d_{\beta \mathrm{N}}(i, i+1) \\
& d_{\mathrm{NN}}(i, i+2) \\
& d_{\alpha \mathrm{N}}(i, i+2) \\
& d_{\alpha \mathrm{N}}(i, i+3) \\
& d_{\alpha \beta}(i, i+3) \\
& d_{\alpha \mathrm{N}}(i, i+4)
\end{aligned}
$$

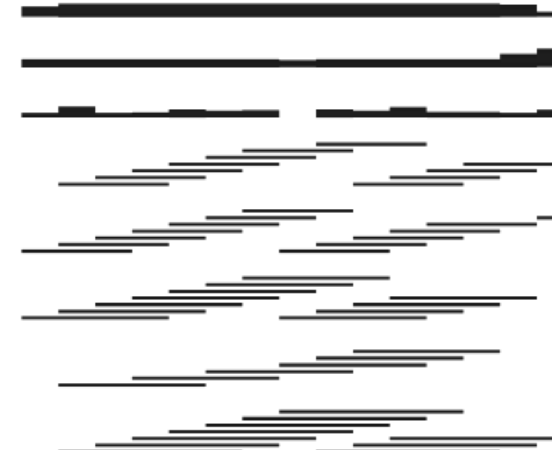

Fig. 1. NOESY data for the synthetic mytilin $\left(22^{\circ} \mathrm{C}, \mathrm{pH} 3.3,100 \mathrm{~ms}\right.$ of mixing time). (A) Selected part showing the dNN NOEs between the amide protons of the helix. The chemical shifts of the S4 and R5 amide are very close, thus the $4 / 5$ dNN NOE cross peaks is on the diagonal. (B) Selected part of the daa NOEs between the $\alpha$ protons of the $\beta$-sheet. In the $x / y$ cross-peak labeling, $x$ is for the residue of which the chemical shift of the considered proton is in the $\mathrm{F} 2$ dimension and $y$ is the residue of which the chemical shift of the considered proton is in the F1 dimension. (C) Summary of the sequential, medium-range, and long-range NOEs. The relative intensity of NOEs is represented by the thickness of the bars. 


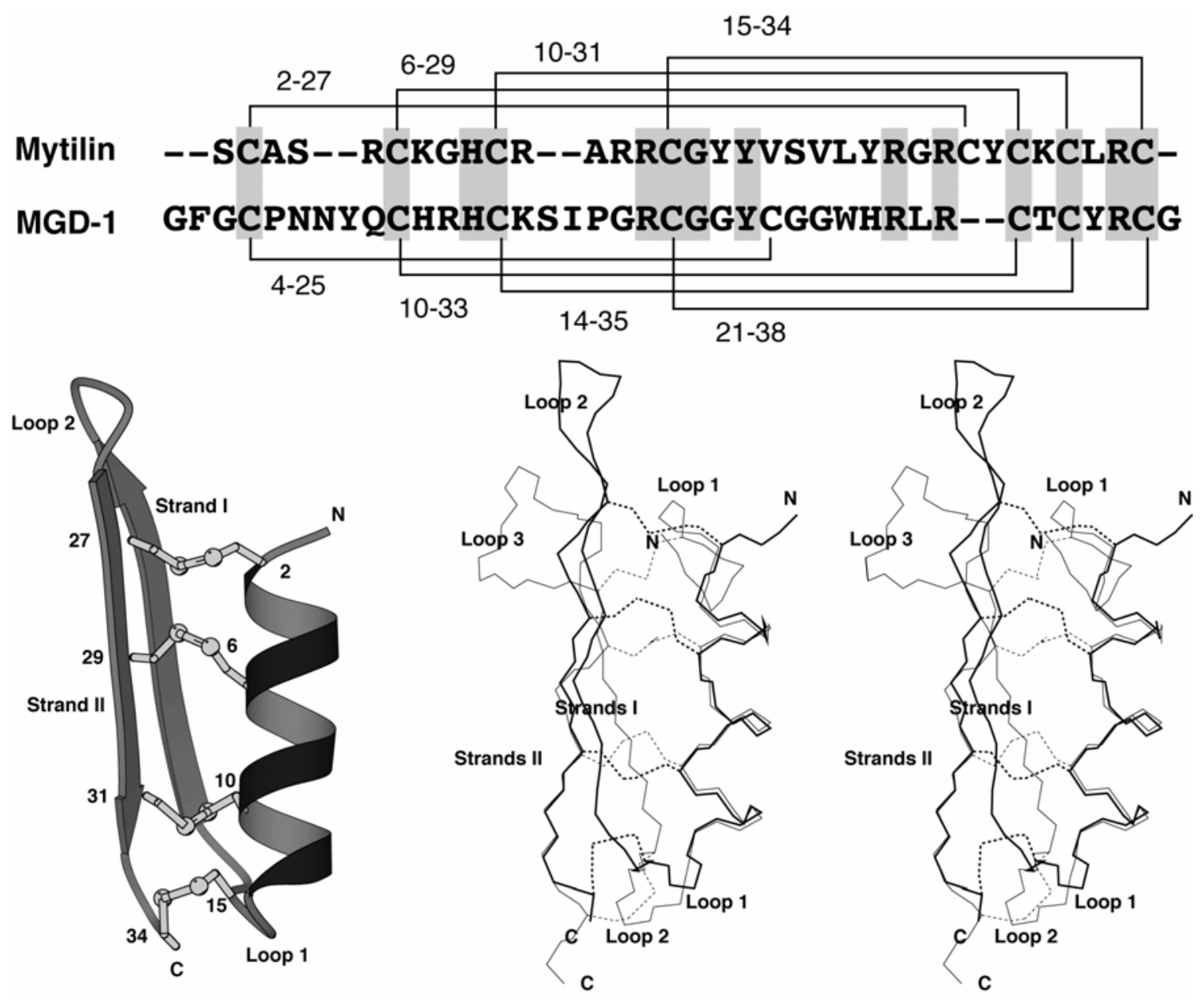

Fig. 2. Sequence alignment and solution structures of mytilin B and MGD-1. Upper panelsequence alignment was obtained by using the online CLUSTAL W (1.83) software at http://www.ebi.ac.uk/clustalw/. Conserved residues are grey shaded. The corresponding disulfide bonds of mytilin (this work) and of MGD-1 [16] are displayed. Lower panel-solution structure of mytilin showing the global fold and the disulfide bond pattern, and stereo view of the mytilin (thick line) and MGD-1 (thin line) structures superimposed by using the 3-12, 16-19, 30-32, and 7-16, 21-24, 34-36 backbone atoms, respectively. For this 17-residues superimposition, a rmsd of $0.92 \AA$ was measured. Disulfide bonds are displayed by dotted lines. 

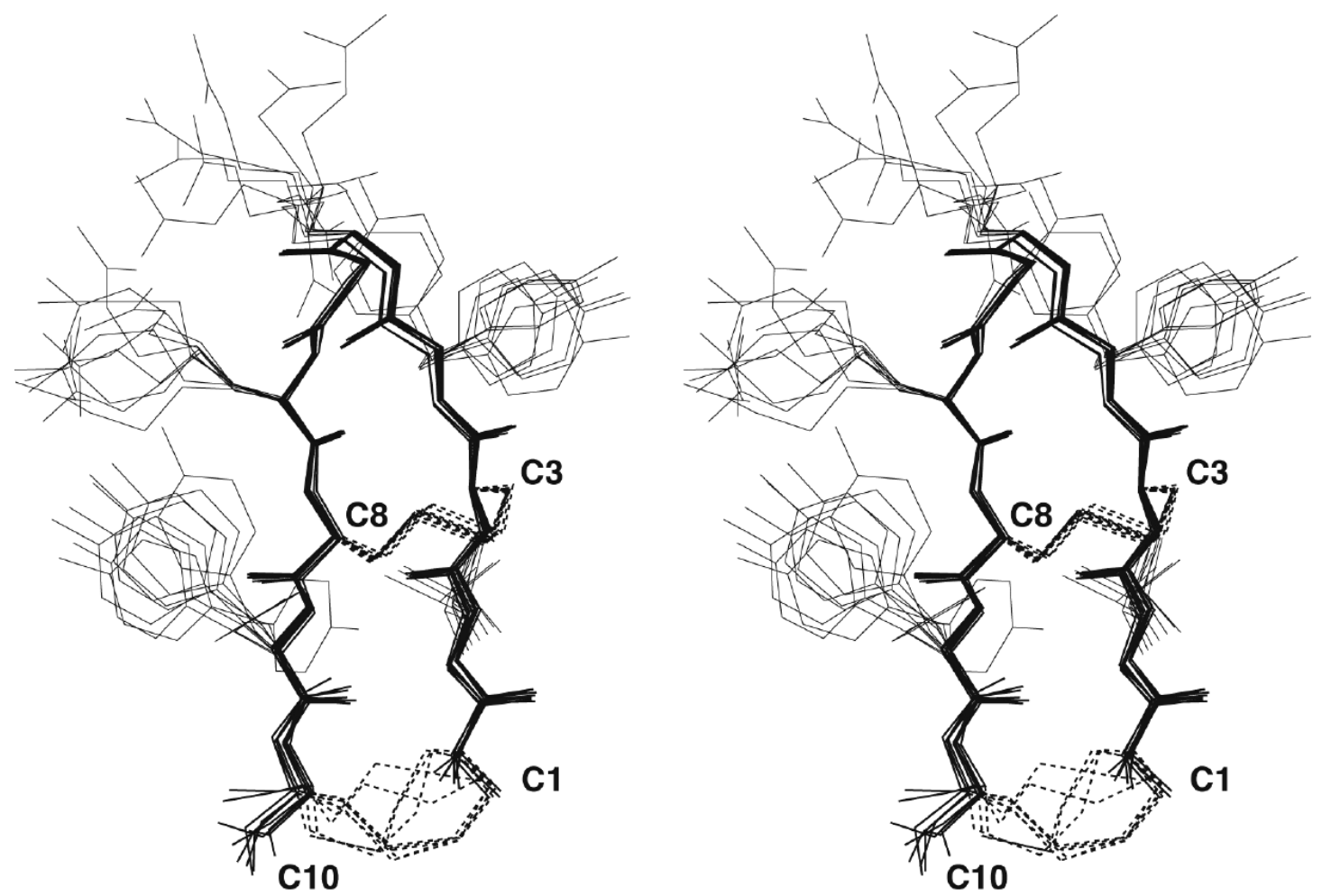

Fig. 3. Stereo view of a family of 10 conformers of the $\mathrm{C} 10 \mathrm{C}$ synthetic peptide as determined by NMR. The backbone atoms were used for the superimposition and a mean pairwise rmsd of $0.48 \pm 0.21 \AA$ was calculated. The two disulfide bonds are displayed by dotted lines. 


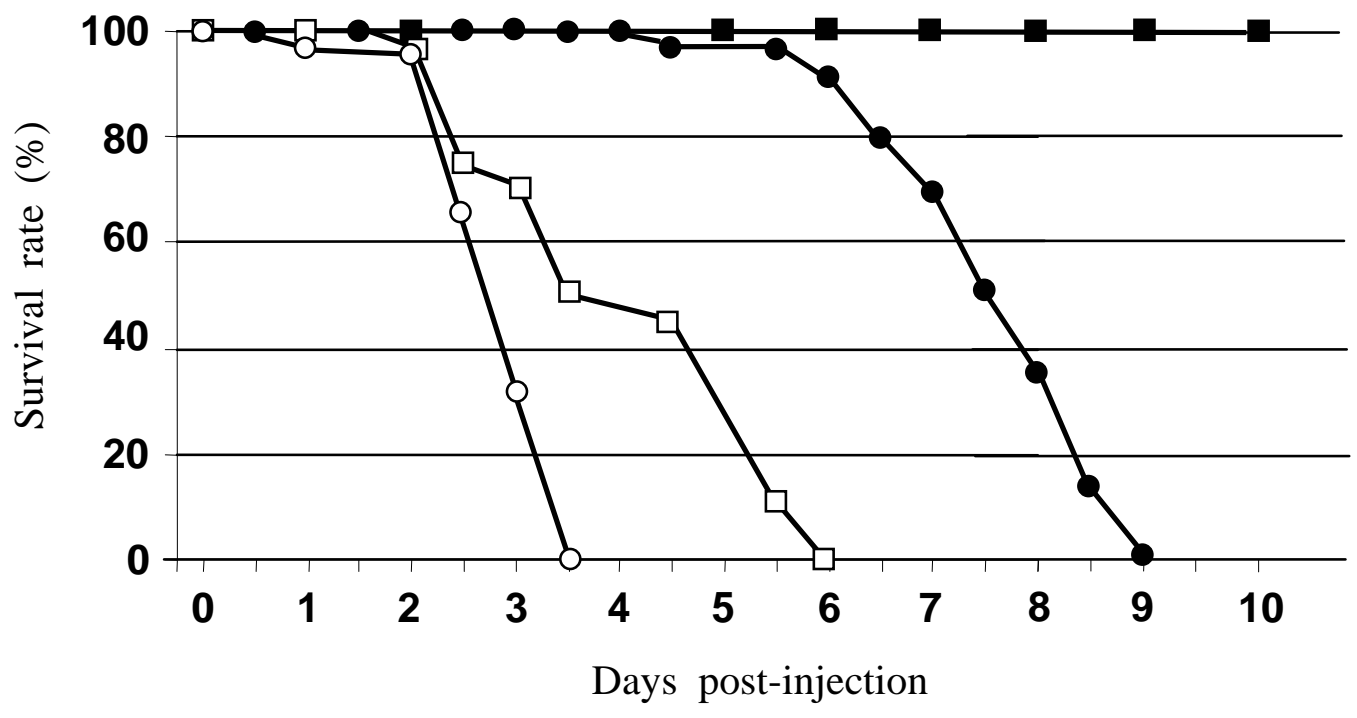

Fig. 4. Difference of susceptibility to WSSV between Litopenaeus japonicus (circle) and Palaemon serratus (square) following injection (open) or per os (close) contact with WSSV, expressed as kinetics of survival. Water temperature $22^{\circ} \mathrm{C} ; n=20$ shrimp per batch. Results are from 1 out of 5 distinct assays. 

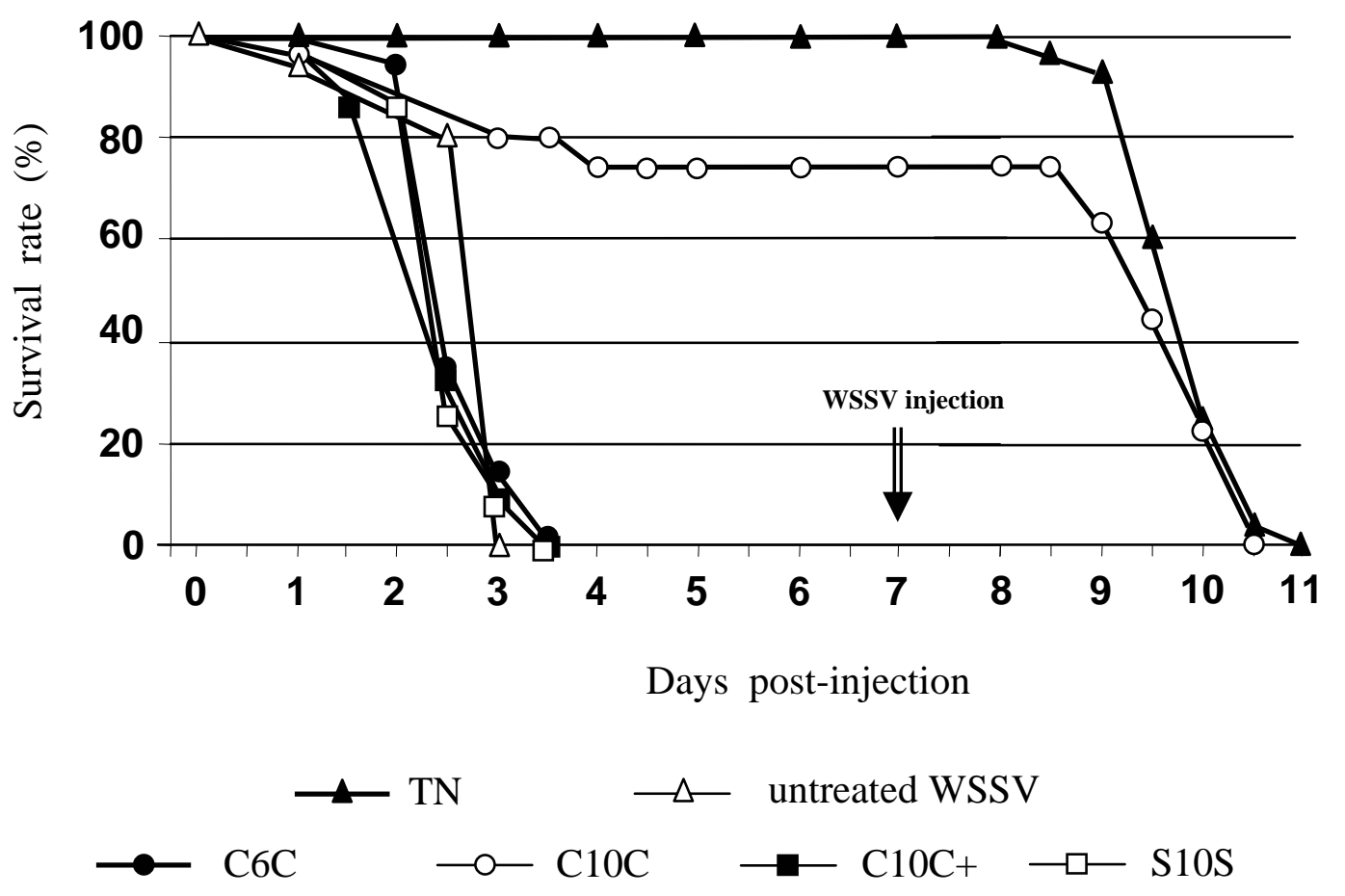

Fig. 5. Survival of $P$. serratus injected with WSSV previously incubated with $50 \mu \mathrm{M}$ of various mytilin B synthetic fragments. A second injection was performed on day 7 (arrow). Note that only pre-incubation with synthetic fragment C10C resulted in less mortality, but was not protecting the shrimp as an injection of non-treated WSSV resulted in $100 \%$ mortality in the next 3.5-4 days. Results are from 1 out of 3 distinct assays. Water temperature $22{ }^{\circ} \mathrm{C} ; n=20-30$ shrimp per batch. TN: $20 \mathrm{mM}$ Tris- $\mathrm{HCl}, \mathrm{pH} 7.4,400 \mathrm{mM} \mathrm{NaCl}$. 


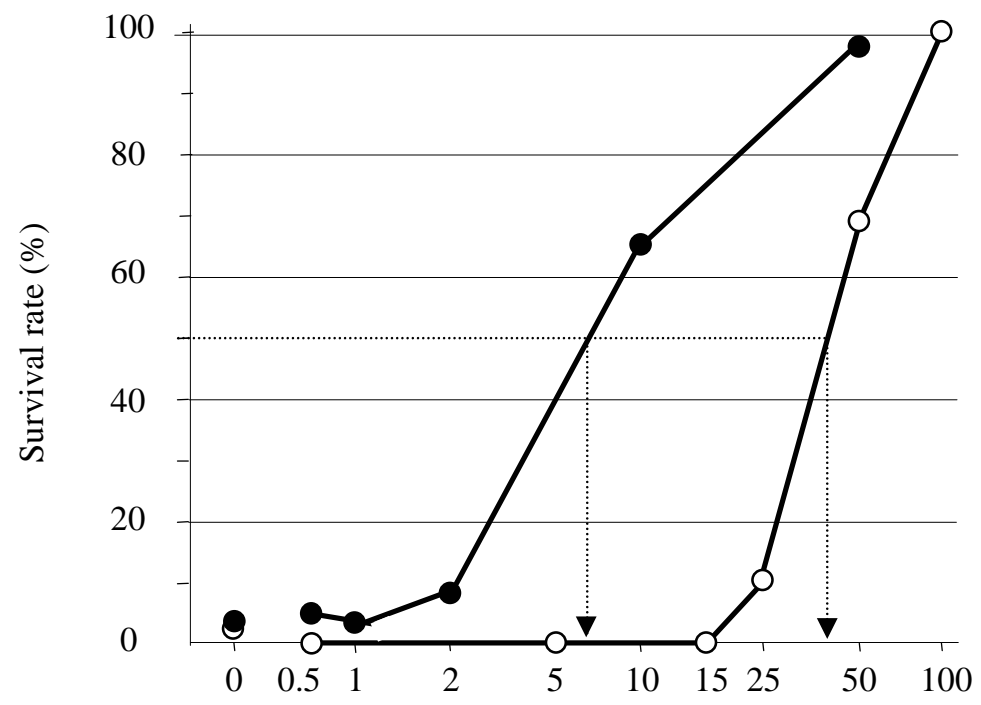

Peptide concentrations, $\mu \mathrm{M}$

Fig. 6. Comparative dose-effects of synthetic mytilin B (close circle) and C10C fragment (open circle) on WSSV-induced mortality on $P$. serratus. Data are from 3.5 days post-injection of WSSV incubated 30 min at $20^{\circ} \mathrm{C}$ with $0,0.5,1,2,5,10,15,25,50$, and $100 \mu \mathrm{M}$. Inhibition doses inducing $50 \%$ survival (IC50) were 7 and $45 \mu \mathrm{M}$ for synthetic mytilin and C10C fragments, respectively. Results are from 1 out of 3 distinct assays. Water temperature $21^{\circ} \mathrm{C}, n=25$ shrimp per batch. 


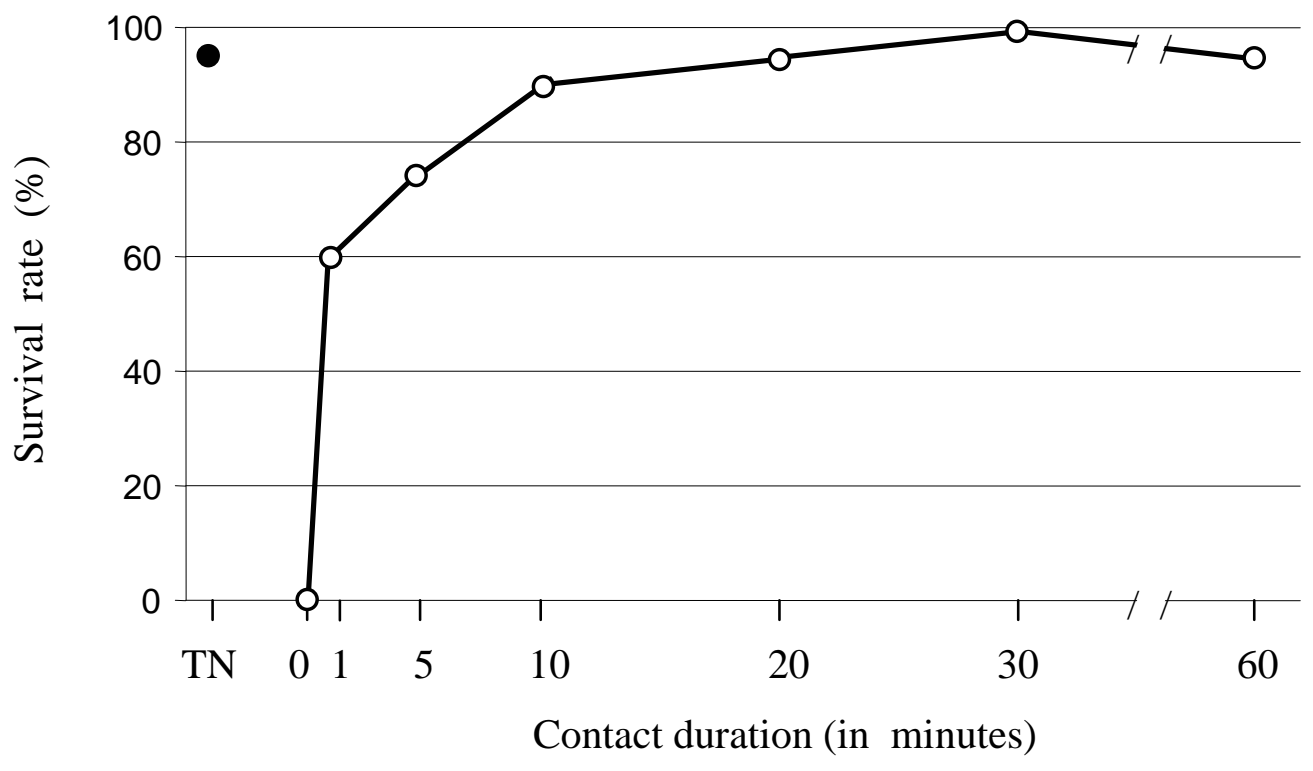

Fig. 7. Effect of contact duration between WSSV and $100 \mu \mathrm{M}$ of C10C on infectious capacity of WSSV on $P$. serratus. Data are from 3.5 days post-injection. Water temperature $22{ }^{\circ} \mathrm{C}, n=20-40$ shrimp per batch. TN: $20 \mathrm{mM}$ Tris- $\mathrm{HCl}, \mathrm{pH} 7.4,400 \mathrm{mM} \mathrm{NaCl}$. 


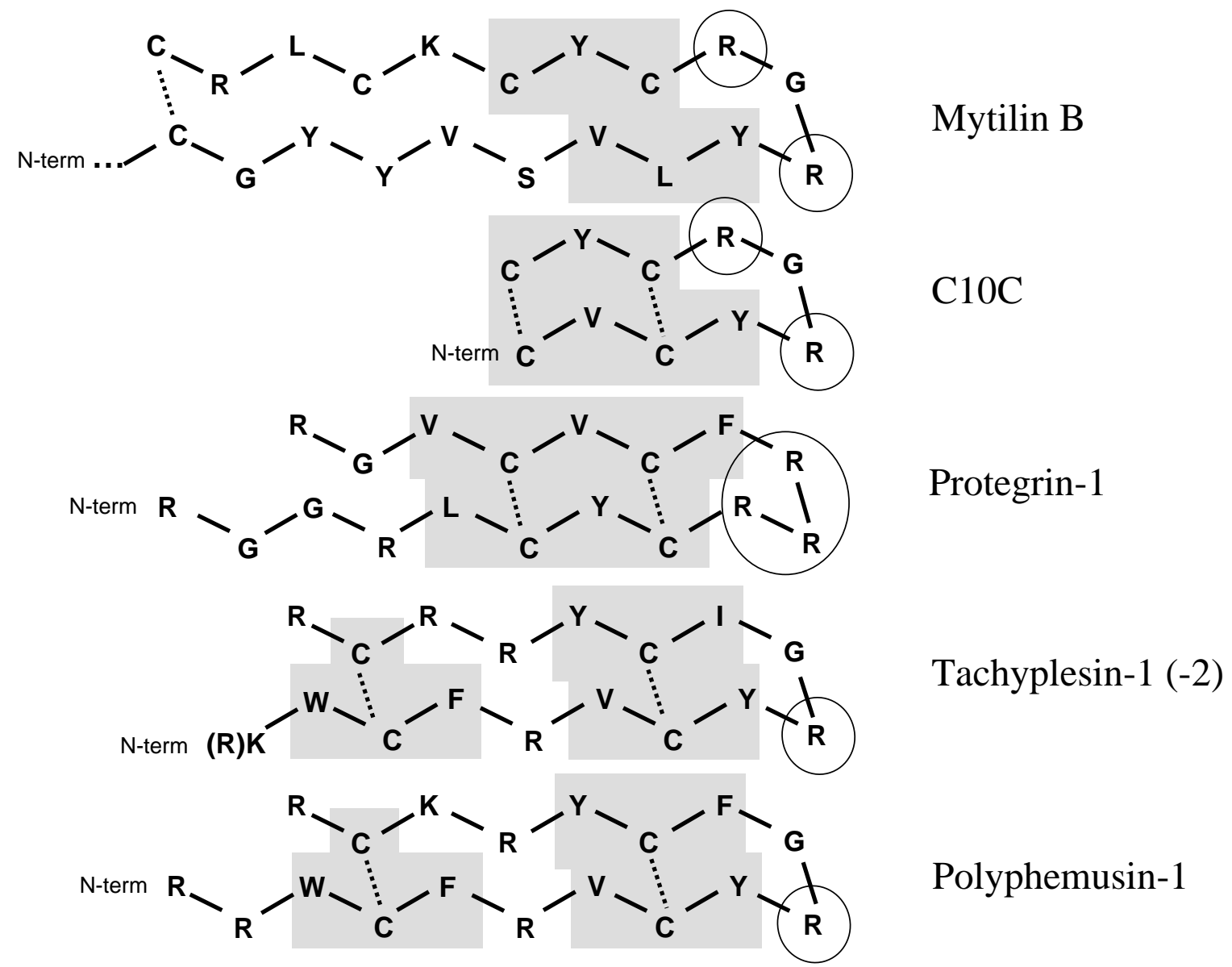

Fig. 8. Scheme of selected $\beta$-hairpin sequences. Mytilin and $C 10 C$ sequences are compared with natural antimicrobial peptides protegrin-1, tachyplesin-1 and (-2), and polyphemusin-1. Positively charged residues located in the $\beta$-turns are circled. Dark gray boxes refer to residues of the adjacent hydrophobic clusters. 